\title{
Elevated Iron Levels in Machine-Grinded Cassava (Manihot esculenta, Euphorbiaceae) in Iwo, Southwest Nigeria as Determined by Atomic Absorption Spectrometry
}

\author{
Oladipo Olukunle Adejumo (Corresponding author) \\ Dept. of Physics and Solar Energy, Bowen University \\ PMB 284, Iwo, Osun State, Nigeria \\ Oluwadara Abosede Oyelowo \\ Dept. of Physics and Solar Energy, Bowen University \\ PMB 284, Iwo, Osun State, Nigeria
}

Olufunmilayo Ebunoluwa Adejumo

Dept. of Pharmaceutical and Medicinal Chemistry, Olabisi Onabanjo University

PMB 2002, Ago-Iwoye, Ogun State, Nigeria

Received: August 18, 2019 Accepted: November 2, 2019 Published: November 5, 2019

doi:10.5296/jfs.v8i1.15287

URL: https://doi.org/10.5296/jfs.v8i1.15287

\begin{abstract}
The potential of trace amounts of elements to contaminate food during processing in some local communities of Nigeria has since been a subject of concern. In Iwo, South West Nigeria, the processing method of converting the highly perishable cassava tubers to more stable products such as the roasted granular product, Gari involves grating/grinding of peeled cassava tubers and this process is suspected to introduce trace elements into the final product. This
\end{abstract}




\section{MInstitute ${ }^{\text {Macrothink }}$}

study determined and compared the levels of trace elements in peeled and machine-grinded cassava tuber samples. Peeled cassava tuber samples and machine-grinded cassava tuber samples were collected, prepared by acid digestion and filtration. Elemental analysis was carried out using PG-990 Atomic Absorption Spectrophotometer in the flame configuration mode. Iron $(9.500 \pm 0.025 \mathrm{mg} / \mathrm{kg})$, Copper $(11.200 \pm 0.025 \mathrm{mg} / \mathrm{kg})$ and Magnesium $(251.317 \pm$ $0.038 \mathrm{mg} / \mathrm{kg}$ ) were present in the peeled cassava tubers; while for the machine-grinded cassava tubers, Iron $(63.075 \pm 0.025 \mathrm{mg} / \mathrm{kg})$, Copper $(11.650 \pm 0.025 \mathrm{mg} / \mathrm{kg})$, Magnesium $(250.500 \pm$ $0.250 \mathrm{mg} / \mathrm{kg})$ and Manganese $(0.650 \pm 0.025 \mathrm{mg} / \mathrm{kg})$ in addition were present. Comparison of these results revealed that Iron concentrations for machine-grinded cassava tubers were significantly higher than peeled cassava tubers $(\mathrm{p}<0.05)$. This result suggests that the grinding process during cassava preparation might have introduced Iron, a trace element contaminant to the product (Gari). This report reveal that the appropriate health authorities and regulatory agencies need to set limits with a view of safeguarding consumers' health.

Keywords: Atomic Absorption Spectrometry, Cassava, Contaminants, Elemental analysis, Public health

\section{Introduction}

Manihot esculenta, (Euphorbiaceae) originating from Brazil and Paraguay (Stephen, 1995) and commonly referred to as cassava, is considered to be the third most important source of food in the tropical and sub-tropical regions of the world, coming behind rice and maize (Cock, 1985). Cassava is a major source of carbohydrate for the tropical population (Onwueme, 1978; Wheatley et al., 1995). It is also the staple food of at least 500 million people (Cock, 1985). The Food and Agriculture Organisation, (FAO) of the United Nations (UN), viewed Nigeria as the largest producer of cassava in the world, ahead of Thailand, Brazil and others. (FAO, 2006). The FAO also views cassava production in other African countries, the Democratic Republic of the Congo, Ghana, Madagascar, Mozambique, Tanzania and Uganda as appearing small in comparison to Nigeria's substantial output. Fresh cassava tubers are highly perishable, hence cannot be kept in fresh conditions for more than a few days after harvest without serious deterioration in quality (Leaky and Wills, 1977). Consequently, to extend its shelf life, some processing methods have been devised locally to convert the highly perishable tubers to more stable products and at the same time reduce its toxicity. One such form is a roasted granular product prepared from peeled, fermented, grated/grinded cassava tubers known as Gari (Asiedu, 1989). The process of grating/grinding of peeled cassava tubers locally is suspected to introduce trace element contaminants to the product at admissible or toxic doses which need to be evaluated, hence this study. These metals, when taken into the body through food contamination cause damage to human health (Obanijesu \& Olajide, 2009). It is well established that high exposure to trace metals in cassava could result in an array of diseases to both human and animals (Idakwoji, 2016). Food safety therefore is an important aspect of a nation's economic stability (Onianwa et al., 1999; Adekunle \& Akinyemi, 2004). Although these elements rarely reach a level of toxic concentration after ingestion, there is still need to control their presence and set limits consequent of the very small difference that exists between their permissible and toxic doses. Atomic absorption spectroscopy (AAS) was employed to determine selected chemical 


\section{Macrothink}

elements present and their concentrations in peeled cassava tubers and in machine-grinded cassava tubers respectively. Previous studies by AAS have confirmed the presence of high levels of metal contaminants in food crops like cassava and plantain particularly in oil-exploration communities while lower levels were reported in non-oil impacted soils (Ndiokwere \& Ezihe, 1990; Hart et al., 2005; Idodo-Umeh \& Ogbeibu, 2010; Echem, 2010; Kalagbor et al., 2015). Metals are substances possessing high electrical conductivity, malleability, and lustre, which can lose their electrons to form cations. These metals are abundant in the earth's crust and are variously distributed in the atmosphere. They are monitored by the properties of the given metal and various environmental factors (Khlifi \& Hamza-Chaffai, 2010). Iwo, South-west Nigeria where our study was carried out is a non-oil impacted community. Results of studies like this, and its practical relevance for human nutrition and public health need to be carefully evaluated in the attempt to interpret dietary analyses in a diagnostic context. Heavy metals are known to bio-accumulate in the system and portend a serious health risk. Ingestion of heavy metals is known to disrupt important physiological processes in living cells and is reportedly associated with serious systemic pathological conditions including cancer (Jaishankar et al., 2014; Adejumo et al., 2016). Additionally, standards need to be set and enforced in the cassava processing centres. Hence, this study determined and compared the levels of selected trace elements in peeled and machine-grinded cassava tuber samples from Iwo, south-west, Nigeria.

\section{Materials and Methods}

\subsection{Sample Preparation}

Peeled cassava tuber samples and machine-grinded cassava tuber samples were collected from some cassava processing centres in Iwo, south-West Nigeria. Collected samples were prepared by air-drying and acid digestion at the Chemistry Laboratory of the Bowen University, Iwo. One gram $(1 \mathrm{~g})$ each of the samples was measured analytically and concentrated $\mathrm{HNO}_{3}(5 \mathrm{ml})$ was added in a Teflon beaker and heated on a hot plate for about 10 min after which perchloric acid $(1 \mathrm{ml})$ was added and then heated for about $30-45 \mathrm{~min}$. The digested sample was cooled to room temperature and filtered. The filtrate was then transferred into a volumetric flask $(25 \mathrm{ml})$ and made up with distilled water. Two other replicate samples were prepared to achieve triplicate measurements in both cases. The digested samples were analysed with the line source PG 990 Atomic Absorption Spectrophotometer, LS AAS, used in the flame configuration mode. It is a fully automated instrument for flame and/or graphite furnace analysis, incorporating two background correction systems, the deuterium lamp method and the self-reversal method.

\subsubsection{Atomic Absorption Spectrometric Analysis}

Air was allowed to mix with acetylene gas from the gas cylinder in good proportion to ignite the burner of the Spectrophotometer. Immediately after ignition, the spectrophotometer was calibrated using the blank (distilled water) and standard solution (as supplied with the spectrophotometer). The aerosol of the sample was then aspirated through the nebulizer into the flame for analysis. Analysis was done for each element of interest at their specific wavelength using the hollow cathode lamp of the element under investigation and the result was displayed on the computer read-out. 


\section{Results}

We measured mean concentrations of selected elements for peeled and machine-grinded cassava tuber samples respectively. The mean concentrations of the elements, $\mathrm{Mn}, \mathrm{Zn}, \mathrm{Pb}, \mathrm{Fe}$, $\mathrm{Cu}$ and $\mathrm{Mg}$ analysed for both groups is presented in Table 1. Mean concentrations for manganese, zinc and lead for peeled cassava tubers were not detectable while it was quantifiable for manganese in machine-grinded tubers. Zinc and lead could also not be detected in machine-grinded tubers. The method detected iron, copper and magnesium for both categories of samples. There were no significant differences in both groups of samples for copper and magnesium; although a significantly greater mean concentration of iron was observed for the machine-grinded tubers. Data has been presented at $95 \%( \pm 2 \mathrm{~S})$ confidence level for triplicate measurements in each of the cases. Table 2 shows the daily dietary allowance for the elements analysed as recommended by National Research Council, USA, (Recommended Dietary Allowances, 2011).

Table 1. Mean values for determined elements in cassava samples

\begin{tabular}{lcc}
\hline Elements & \multicolumn{2}{c}{ Concentrations $(\mathrm{mg} / \mathrm{kg})$} \\
& Peeled Cassava Tubers & Machine-Grinded Tubers \\
\hline Manganese & $\mathrm{Nd}$ & $0.650 \pm 0.025$ \\
Zinc & $\mathrm{Nd}$ & $\mathrm{Nd}$ \\
Lead & $\mathrm{Nd}$ & $\mathrm{Nd}$ \\
Iron & $9.500 \pm 0.025$ & $63.075 \pm 0.025$ \\
Copper & $11.200 \pm 0.025$ & $11.650 \pm 0.025$ \\
Magnesium & $251.317 \pm 0.038$ & $250.500 \pm 0.250$ \\
\hline
\end{tabular}

$\mathrm{Nd}=$ Not detected.

Table 2. Recommended dietary allowances per day of elements for humans

\begin{tabular}{lllllll}
\hline & \multicolumn{5}{c}{ Recommended Dietary Allowances per day, (Elements) in mg/d } \\
& Age Group & Mn & Zn & Fe & Ca & Mg \\
\hline Children & $4-8$ years & 1.5 & 5 & 10 & 1000 & 130 \\
Males & $14-18$ years & 2.2 & 11 & 11 & 1300 & 410 \\
& $31-50$ years & 2.3 & 11 & 8 & 1000 & 420 \\
& $51-70$ years & 2.3 & 11 & 8 & 1000 & 420 \\
& $>70$ years & 2.3 & 11 & 8 & 1200 & 420 \\
& $14-18$ years & 1.6 & 9 & 15 & 1300 & 360 \\
& $31-50$ years & 1.8 & 8 & 18 & 1000 & 320 \\
& $51-70$ years & 1.8 & 8 & 8 & 1200 & 320 \\
\hline
\end{tabular}




\section{$\underline{\Lambda \text { Macrothink }}$}

\begin{tabular}{lllcccc}
\hline \multirow{4}{*}{ Pregnancy } & $>70$ years & 1.8 & 8 & 8 & 1200 & 320 \\
& $14-18$ years & 2.0 & 12 & 27 & 1300 & 400 \\
& $19-30$ years & 2.0 & 11 & 27 & 1000 & 350 \\
& $31-50$ years & 2.0 & 11 & 27 & 1000 & 360 \\
Lactation & $14-18$ years & 2.6 & 13 & 10 & 1300 & 360 \\
& $19-30$ years & 2.6 & 12 & 9 & 1000 & 310 \\
& $31-50$ years & 2.6 & 12 & 9 & 1000 & 320 \\
\hline
\end{tabular}

(Source: Recommended Dietary Allowances, National Academies Press (US); 2011.

\section{Discussion}

Comparison of the results in Table 1, revealed that iron concentrations for the peeled cassava tubers $(9.500 \pm 0.025 \mathrm{mg} / \mathrm{kg})$ and the machine-grinded cassava tubers $(63.075 \pm 0.025 \mathrm{mg} / \mathrm{kg})$ showed a marked significant difference $(\mathrm{p}<0.05)$ while the other elements displayed no significant differences. This result suggested that the process of grinding cassava might have introduced trace element contaminants, in this case; iron to the product (Gari). Also, comparing the iron content of $63.075 \pm 0.025 \mathrm{mg} / \mathrm{kg}$ obtained for the machine-grinded cassava tubers (Table 1) with the Recommended Dietary Allowance, (RDA) for varying age and gender groups as shown in table 2, we observe that for children, the RDA is $10 \mathrm{mg}$ per day, for males in the age group $14-18$ years, the RDA is $10 \mathrm{mg} / \mathrm{d}$ and for other age groups it is $8 \mathrm{mg} / \mathrm{d}$. For females, the RDA is $15 \mathrm{mg} / \mathrm{d}$ in the age group $14-18$ years, $18 \mathrm{mg} / \mathrm{d}$ in the $31-50$ years age group and $8 \mathrm{mg} / \mathrm{d}$ for the other age groups. For all age groups for pregnant women, the RDA is $27 \mathrm{mg} / \mathrm{d}$. For lactating women in the $14-18$ years age group, the RDA is $10 \mathrm{mg} / \mathrm{d}$ and it is 9 $\mathrm{mg} / \mathrm{d}$ for other age groups. Heavy consumption of the product (Gari) by consumers may not conform to these tolerable limits of the RDA values for varying age/gender groups. Previous studies in the riverine area of Nigeria also reported elevated levels of iron $(92.40 \mathrm{mg} / \mathrm{kg})$ in cassava and other crops (Hart et al., 2005; Kalagbor et al., 2015) consequent of heavy metal pollution of an oil-exploration area.

The current study has nutritional implications and appreciation of the modifying action of factors likely to influence iron trace-element intake in Gari is a promoter of studies like this. Solomons and Jacob, in 1981, stated that iron and zinc are the two most abundant trace minerals in the human body and these elements play a significant role in health and disease. Zinc is an important nutritive factor as well as a co-factor for many metalloenzymes. Zinc is also required for growth and cell-division and its deficiency is associated with syndromes that cause short stature and dwarfism (Wells et al., 1987); aside leading to a decrease in blood urea nitrogen (BUN) and increase in blood ammonia (Smith et al., 1973). Iron is contained in haemoglobin and important for maintaining a healthy immune system; it also aids the digestion of certain foods. The bioavailability of iron which is defined as the extent to which iron is absorbed from the diet and used for normal body functions (Hurrell and Egli, 2010) is approximately $14 \%$ to $18 \%$ from mixed diets that include substantial amounts of meat, seafood and vitamin C. Heme iron found in animal foods that contain hemoglobin, such as 


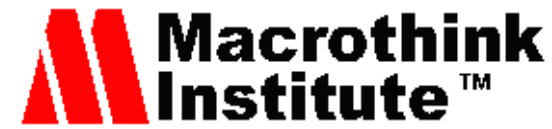

meat, fish and poultry is the best form of iron for us, because our bodies readily absorb up to $40 \%$ of it. On the other hand, the non-heme iron from plant-based protein is less readily absorbed by our bodies. Therefore the heme iron is a large source of dietary iron for humans ("Iron-Fact Sheet for Health Professionals," 2019). We believe that dietary iron, usually in form of iron compounds containing iron in the oxidized form may be part of a healthy diet, but metal is not (Ries, 2014). Food safety is a serious concern for every food manufacturer and one contaminant that can cause some consumer pain and grief is a piece of metal. Metal is not a trace mineral we expect to find in our food. The food production industry is run on machinery, and consequently, contaminants may sometimes enter the production line, which need to be checked. Though iron is used in the body to make tendons and ligaments, and certain chemicals in the brain are controlled by the presence or absence of iron; excess iron levels can enlarge the liver, may provoke diabetes and cardiac failure. Haemochromatosis, a genetic disease is equally a condition resulting from excessive iron absorption. Therefore, the effect of increased Fe level in the machine-grinded cassava tubers and hence the final product (Gari) on the uptake and transport of these two most abundant dietary trace minerals in the human body cannot be overemphasized and may need further investigation. Results of this and similar studies, and its practical relevance for human nutrition especially with respect to the magnitude of the "iron effect" need to be carefully balanced when striving to interpret dietary analyses in a diagnostic context. Iron accumulation is reportedly related to certain neurological disorders such as Alzheimer disease, Parkinson disease, type 1 neurodegeneration with brain iron accumulation, and other disorders (Sadrzadeh and Saffari, 2004) which are undesirable.

\section{Conclusion}

We conclude therefore, that machine-grinded cassava tubers in Iwo, south-west Nigeria are contaminated with iron. Suspected introduction of trace element contaminants such as iron to the product (Gari) as a consequence of the cassava grinding process require that the rusty conditions of the grinders be addressed by appropriate health authorities and regulatory agencies. Since metal toxicity depends upon the absorbed dose, the route and duration of exposure whether acute or chronic that can cause various disorders (Jaishankar et al., 2014); it is necessary to set standards for these elements and enforce compliance particularly in a country like Nigeria where the product is heavily consumed with a view to safeguarding public health.

\section{Acknowledgement}

This research did not receive any specific grant from funding agencies in the public, commercial or not-for-profit sectors.

\section{References}

Adejumo, O. E., Fasinu, P. S., Odion, J. E., Silva, B. O., \& Fajemirokun, T. O. (2016). High Cadmium Levels in cured Meat Products Marketed in Nigeria - Implications for Public Health. Asian Pacific Journal of Cancer Prevention, 17(4), 1933-1936. https://doi.org/ 10.7314/APJCP.2016.17.4.1933 


\section{Macrothink}

Journal of Food Studies ISSN 2166-1073 2019, Vol. 8, No. 1

Adekunle, M. I., \& Akinyemi, M. F. (2004). Lead Levels of Certain Consumer Products in Nigeria: A Case Study of Smoked Fish Foods from Abeokuta. Food and Chemical Toxicology, 42(9), 1463-1468. https://doi.org/10.1016/j.fct.2004.04.007

Asiedu, J. J. (1989). Processing of Tropical Crops. London: Macmillan Publishers Ltd.

Cock, J. H. (1985). Cassava: New Potential for a Neglected Crop. Boulder, Colorado, USA: Westview Press Inc.

Echem, O. G. (2010). Analysis of heavy metals (Lead Pb, Cadmium Cd, Chromium Cr, and Cobalt Co) content of Cassava (Manihot esculenta crantz) cultivated on oil polluted soil in Ogoni land, Nigeria. International Journal of Pure and Applied Sciences, 3(4), 23-30.

FAO. (2006). Cassava Production, Processing and Marketing Project. Bankable Investment Project Profile, Vol. IV, Food and Agriculture Organisation of the United Nations.

Hart, A. D., Oboh, C. A., Barimalaa, I. S., \& Sokari, T. G. (2005). Concentrations of trace metals (lead, iron, copper and zinc) in crops harvested in some oil prospecting locations in Rivers State, Nigeria. African Journal of Food Nutrition Science, 5(2), 1-21.

Hurrell, R., \& Egli, I. (2010). Iron Bioavailability and Dietary Reference Values. The American Journal of Clinical Nutrition, 91(5), 14615-14675. https://doi.org/10.3945/ ajcn.2010.28674F

Idakwoji, P. A. (2016). Assessment of Heavy Metal Contamination of Soil and Cassava Plants Within the Vicinity of a Cement Factory in North Central Nigeria. Advances in Applied Science Research, 7(3), 20-27.

Idodo-Umeh, G., \& Ogbeibu, A. E. (2010). Bioaccumulation of the Heavy Metals in Cassava Tubers and Plantain fruits grown in soils impacted with petroleum and non-petroleum activities. Research Journal of Environmental Sciences, 4, 33-41. https://doi.org/10.3923/ rjes.2010.33.41

Iron-Fact Sheet for Health Professionals. (2019, October 16). Retrieved from https://ods.od.nih.gov/factsheets/iron-HealthProfessional/ (Updated)

Jaishankar, M., Tseten, T., Anbalagan, N., Mathew, B. B., \& Beeregowda, K. N. (2014). Toxicity, Mechanism and Health Effects of some Heavy Metals. Interdisciplinary Toxicology, 7(2), 60-72. https://doi.org/10.2478/intox-2014-0009

Kalagbor, I. A., Dighi, N. K., \& James, R. (2015). Levels of some Heavy Metals in Cassava and Plantain from Farmlands in Kaani and Kpean in Khana Local Government Area of Rivers State. Journal of Applied. Science and Environmental Management, 19(2), 219-222. https://doi.org/10.4314/jasem.v19i2.7

Khlifi, R., \& Hamza-Chaffai, A. (2010). Head and Neck Cancer due to Heavy Metal Exposure via Tobacco Smoking and Professional Exposure: a review. Toxicology and Applied Pharmacology, 248(2), 71-88. https://doi.org/10.1016/j.taap.2010.08.003

Leaky, C. L. A., \& Wills, J. B. (1977). Food Crops of the Lowland Tropics (pp. 80-81). London: Oxford.

Ndiokwere, C. L., \& Ezihe, C. A. (1990). The Occurrence of Heavy Metals in the Vicinity of Industrial Complexes in Nigeria. Environment International, 16(3), 291-295. https://doi.org/ $10.1016 / 0160-4120(90) 90123-\mathrm{N}$ 


\section{Macrothink}

Journal of Food Studies

ISSN 2166-1073

2019, Vol. 8, No. 1

Obanijesu, E. O., \& Olajide, J. O. (2009). Trace Metal Pollution Study on Cassava Flour's Roadside Drying Technique in Nigeria. In E. K. Yanful (Ed.), Appropriate Technologies for Environmental Protection in the Developing World (pp. 333-339). Springer, Dordrecht. https://doi.org/10.1007/978-1-4020-9139-1_32

Onianwa, P. C., Adetola, I. G., Iwegbue, C. M. A., Ojo, M. F., \& Tella, O. O. (1999). Trace Heavy Metals Composition of Some Nigerian Beverages and Food Drinks. Food Chemistry, 66(3), 275-279. https://doi.org/10.1016/S0308-8146(98)00257-X

Onwueme, I. C. (1978). Tropical Tuber Crops: Yams, Cassava, Sweet Potato and Cocoyams. Chichester: John Wiley \& Sons Ltd.

Recommended Dietary Allowances. 2011. National Academy of Sciences, 2011. National Academies Press (US); 2011.

Ries, B (2014, November 9). Iron May Be Part Of A Healthy Diet But Metal Is Not. Retrieved from https://www.thermofisher.com/blog/food/iron-may-be-part-of-a-healthydiet-but-metal-is-not/

Sadrzadeh, S. M., \& Saffari, Y. (2004). Iron and Brain Disorders. American Journal of Clinical Pathology, S64-70. https://doi.org/10.1309/EW0121LG9N3N1YL4

Smith, J. C. Jr, McDaniel, E. G., Fan, F. F., \& Halsted, J. A. (1973). Zinc: A Trace Element Essential in Vitamin A Metabolism. Science, 181(4103), 954-955. https://doi.org/10.1126/ science.181.4103.954

Solomons, N. W., \& Jacob, R. A. (1981). Studies on the Bioavailability of Zinc in Humans: effects of heme and non-heme iron on the absorption of zinc. Journal of Clinical Nutrition, 34, 475-482. https://doi.org/10.1093/ajcn/34.4.475

Stephen, O. K. (1995). Tropical Research and Education Centre. USA: Florida University Press.

Wells, J. L., James, D. K., Luxton, R., \& Pennock, C. A. (1987). Maternal Leucocyte Zinc Deficiency at start of third trimester as a predictor of fetal growth retardation. British Medical Journal, 294, 1054-1056. https://doi.org/10.1136/bmj.294.6579.1054

Wheatley, C., Scott, G. J., Best, R., \& Wiersema, S. (1995). Adding value to root and tuber crops: A Manual on Product Development. Publication No. 247. Columbia: Centro Internacional de Agricultura Tropical, CIAT.

\section{Copyright Disclaimer}

Copyright for this article is retained by the author(s), with first publication rights granted to the journal.

This is an open-access article distributed under the terms and conditions of the Creative Commons Attribution license (http://creativecommons.org/licenses/by/3.0/). 